\title{
Communication Problems: Advantages and Disadvantages of Teaching Autistic Children with Humanoid Robots
}

\author{
Natalya A. Sigacheva* (a), Alfiya R. Baranova (b), Khanif F. Makaev (c) \\ (a), (c) Kazan Federal University, 420008, Kazan (Russia), 18 Kremlyovskaya street, nsigacheva@mail.ru \\ (b) Kazan Innovative University named after V.G. Timiryasov (IEML) \\ 42 Moskovskaya str., Kazan, 420111, Russia
}

\begin{abstract}
The relevance of the investigated problem is caused by the need of society education to be focused on a humanitarian approach to provide education not only to healthy children but also to patients with autism. This article is focused on the search for educational tools using robotic technologies for teaching children with autism a foreign language.

The methods used in this article are based on a comparative analysis of two approaches, such as the traditional method of teaching English and using robotic systems. The article reveals that traditional system of education, organization of the educational process, is not suitable for increasing the number of children with autism.

The main result of the research is the developed criteria for evaluating the effectiveness of strategies for teaching children with autism a foreign language which is based on the analysis of the effectiveness of existing educational tools. Recommendations are developed. Materials of the article can be useful for researchers in this field, teachers dealing with autistic children for enrichment foreign language teaching methodology and pedagogy.
\end{abstract}

Keywords: English language teaching, communication, autistic children, social robotics, humanoid educational robots.

(C) 2020 Natalya A. Sigacheva, Alfiya R. Baranova, Khanif F. Makaev

This is an open access article distributed under the terms of the Creative Commons Attribution License (CC BY 4.0), which permits unrestricted use, distribution, and reproduction in any medium, provided the original author and source are credited.

Published by Kazan federal university and peer-reviewed under responsibility of IFTE-2020 (VI International Forum on Teacher Education)

\footnotetext{
* Corresponding author. E-mail: nsigacheva@mail.ru
} 


\section{Introduction}

Currently, there are a number of serious diseases that prevent the effectiveness of educational processes and the assimilation of knowledge necessary for the realization of the individual and its socialization in society. The problem concerns children with autism. As a special disorder, autism was described in the 40s of the last century. Despite this, until the collapse of the USSR and even after, children were often diagnosed with "child schizophrenia", and spent their lives in psych neurological boarding schools. For a long time in the country, it was believed that children with autism need only care and treatment. It took half a century for autism to be officially recognized as a special type of health disorder in the Soviet Union. This happened in 1989. However, it was not easy to bring this fact to the understanding of doctors, teachers, and society as a whole. Seven years ago, children with autism were considered uneducated in Russia. Only a Federal law «On education in the Russian Federation" adopted at the end of 2012 abolished this approach, recognizing all children as having the right to education (Special Federal State Educational Standard for primary school education of children with autism spectrum disorders).

A prototype of the Special Federal State Educational Standard (FSES) for primary school education of children with autism spectrum disorders (ASD) was developed by specialists of the Institute of Correctional Pedagogy in 2010. This project is currently being tested in pilot regions of Russia. This educational standard allows a child with an autistic component to exercise their right to education regardless of the place of residence, type of educational institution, or severity of the developmental disorder (Recommended BGEP (Basic General Educational Program) «Autism» adopted by the decision of the federal educational-methodical association for general education).

The Federal Educational and Methodological Association for General Education adopted the Prototype of ABGEP (Adapted Basic General Educational Program) Autism, which proposed a system for assessing the achievement of students with autism spectrum disorders with the planned results of mastering the adapted basic general educational program of primary general education (Karpekova, et al., 2016).

\section{Purpose and objectives of the study}

Purpose of the study is to work out criteria and evaluate the effectiveness of strategies for teaching children with autism a foreign language applying the analysis of the effectiveness of existing educational tools.

\section{Literature review}

According to researchers (Esterbrook \& Esterbrook, 2013; Mukhina, 2017; Nemenchinskaya, 2014; Mandy et al., 2016 a), the difficulty of teaching a child suffering from autism spectrum disorder is caused by the 
following problems: lack or absence of communicative skills (lack of spoken speech, inability to initiate or maintain conversation (Mandy et al., 2016 b), limited and/or repeated actions and interests (stereotype, auto aggression, limited behavior, etc. (Hornby, 2015). That is, a special educational approach is needed, in which classes will be held as productively as possible for such a child.

It should be noted that the problem of teaching children with autism spectrum disorder is relevant today. Russian and foreign scientists are interested in the development of communication skills of children with autism. Researchers note that visual interface of the robot, its way of communication with children, social role plays an important role for effective results in learning, getting quick feedback from children with autism (Bearss et al., 2015).

Foreign researchers also study various methods for the development of communication and learning skills of such children (Huijnen \& De Witte, 2017; Vanderborght et al., 2012; Moghadam et al., 2015). A completely new approach, available due to the rapid development of such field of science as robotics, was proposed by Huijnen and de Witte (2017). The researchers considered a method based on teaching a child with ASD (autism spectrum disorder) using a robotic system. Scientists indicate that robot assisted therapy (RAT) or robot mediated intervention (RMI) is considered the most promising method for teaching autistic children communication and social interaction because, communicating with a robot can be more comfortable, easier and more attractive than communicating with a person for such children. The researchers conclude that the most productive learning process is when a robot acts as a teacher (Taheri et al., 2015). At the same time, the area of teaching foreign language to children with autism remains poorly studied.

It is known that the basis of communication skills is the knowledge of the language, often not only native. The above mentioned actualizes the need to consider the strategy of teaching children with autism, a foreign language using humanoid robots.

\section{Methodology}

During the study, both empirical and theoretical methods of scientific research were applied: description and comparative analysis of data to identify the advantages and disadvantages of traditional method or using robotic systems for autistic children in teaching communication in English. The authors use the comparison method to take into account all aspects providing effectiveness process. The following scientific works of such scientists as Alemi et al. (2015), Chang et al. (2010), Huijnen and de Witte (2017), Hornby (2015), Mandy et al.(2016), Taheri et al. (2015), etc. are the basis for the study. 


\section{Results}

To assess the effectiveness of the criteria, we used genuine, real and concrete results of educational activities and performance of the set educational tasks for the child. At the same time, a special set of quantitative and qualitative indicators has been developed for each of these criteria, which contribute to an accurate and verified assessment. Both pedagogical and psychological parameters were used.

Considering the first criteria, namely the status-role characteristics, it was found that children with autism showed the greatest communication activity and feedback with the robot, the interface and communication of which coincided with its role. It should be noted that the students during such lessons more often talk about their fears, about their character, gave more information about their condition, which is very important when conducting classes. It is noted that children show more interest in the process of learning activities with the robot. Tactile contacts with the robot aroused interest among students, which is not always appropriate in the case of a human teacher. In other words, the children were convinced that the situation around them is safe and the teacher-robot is a friend and you can share your experiences with it or ask it for help.

The analyses of the results of training with a human teacher showed that projected expectations were not met in $45 \%$ of cases due to the fact that the teacher was in a higher status role. The teacher received monosyllabic answers, while the children were shackled, felt discomfort, more lost, less concentrated, were more thoughtful, perceived the educational process as discomfort and had long pauses in the answers. This behavior can be described as having weak feedback. When teaching a language, it has a negative effect, because the process of mastering the material becomes more complicated each next lesson.

Analyzing the correct form of problem statement, it should be noted that due to the imperfection of the technical part used in modern robots, a human teacher copes with this teaching problem much better than robots. Studies indicate that $85 \%$ of teachers can confidently cope with the exact setting of the educational task, taking into account the level of knowledge, the amount of knowledge acquired, and the psychoemotional state of the student.

Considering learning environment as creating favorable conditions for high communicative activity of children with autism as the third criterion, it was found that there are almost no serious differences between the two educational strategies, but in the case of a robot, we cannot change the teacher. One robot can be used for different subjects, respectively; there is no need to get used to the speech characteristics, appearance, behavior and the method of teaching. In the case of a human teacher, this is not always guaranteed. The results of the work confirm $75 \%$ of successful training activities using robots and $65 \%$ of effective training activity with a teacher. 
An important and necessary aspect of working with autistic children is the development of an individual educational plan. Since the student's intellectual, mental, physical, and emotional state changes daily, it is difficult or even impossible to reprogram the robot to solve an urgent problem. According to most researchers, in this case, the human teacher has an undeniable advantage. Pilot studies have shown that 99.5\% of teachers are able to assess a child`s capabilities and create a correct, the most productive individual curriculum.

The last criterion, namely home education, allows evaluating the effectiveness of two compared technologies while teaching a child at home. It was found that the human teacher copes with the task of teaching at home better than a robot teacher, due to a number of reasons. Firstly, currently there are no such robots that could accurately determine in which areas the child does not have enough knowledge in contrast to the human teacher. Secondly, development of a personal robot for each child suffering from autism is a very costly and time-consuming process. Thirdly, to use a training robot at home, you need a trained, technical Troubleshooting specialist with pedagogical skills as an accompanying each lesson.

The results of the comparative analysis of the effectiveness of the developed criteria, depending on the choice of educational strategy, are listed in the table (Table 1).

Table 1. Comparison of traditional and robotic educational strategies effectiveness

\begin{tabular}{|l|l|l|l|}
\hline № & Criteria & $\begin{array}{l}\text { Robotic } \\
\text { educational } \\
\text { technology }\end{array}$ & $\begin{array}{l}\text { Traditional } \\
\text { educational } \\
\text { technology }\end{array}$ \\
\hline 1. & Status-role characteristics & $85 \%$ & $55 \%$ \\
\hline 2. & Problem statement & $45 \%$ & $85 \%$ \\
\hline 3. & Learning environment & $75 \%$ & $65 \%$ \\
\hline 4. & Individual educational plan & $35 \%$ & $99,6 \%$ \\
\hline 5. & Homeschooling & $18 \%$ & $98 \%$ \\
\hline
\end{tabular}

\section{Discussions}

To study the problem, it is necessary to consider such a term as autism. The most acceptable by scientists is such a definition: autism is a disorder in which a person has a lack of social interaction and communication, and this disorder is characterized by limited interests and repetitive actions. According to the researchers 
Taheri et al. (2015), Pour et al. (2018), Chang et al. (2010), Zilberman et al. (2015), autistic children, despite their passivity to communicate with anyone, enjoy working with various technological devices, such as robots and computers. So it can be assumed that humanoid robots have great potential in helping children with ASD in learning foreign languages, considering that children must be provided with special learning strategies. It should be noted that in order to optimize learning a foreign language in the classroom, students must communicate with each other in English, which can be quite difficult for children with autism. We agree with Karpekova (2016) that, communication can make them worry, which will lead to low learning outcomes in the classroom. Therefore, it is necessary to develop a learning environment in which it is possible to reduce the level of anxiety of children with autism and increase their productivity. The detailed and thorough analysis of the research works of domestic and foreign experts and our own experience allows us to work out criteria in order to evaluate the effectiveness of standard and robotic educational strategies.

The first criterion under consideration is the status-role characteristics of the teacher. Here it is necessary to take into account such qualities of a teacher as his manner of communication, appearance and positioning. Status is a local characteristic of a person, and the closely related concept of social role which refers to the behavior expected of people with a certain status in accordance with the norms accepted in this society.

Another criterion is the correct form of problem statement. Using special learning strategies, children with ASD are able to learn a foreign language. Such children have difficulty in maintaining social communication, which is extremely important when learning English, thus you need some way to reward them for their attempts to communicate. Otherwise, the child may have negative factors such as confusion, stress, discomfort. It should also be borne in mind that it is necessary to duplicate the current task either verbally or in writing every time the child begins to be distracted from classes (Voloshin, 2016).

Another criterion is learning environment. That is providing favorable conditions for high communicative activity of children with autism. Accordingly, the first session each day should start with some breaks. Also, there should be no sharp changes in activities, if we talk about the transition from physical education to a subject that requires other activity(mental), and mental - in the transition from a humanitarian subject to technical, where it is necessary to apply different approaches to the processing of information received by them.

The next criterion under consideration is the features of the individual educational plan. In most schools it is impossible to organize the educational process so that children with different levels of socialization are engaged in the same class. That is, children with autism even if they are socialized usually have a lower level of perception in the standard class. 
Finally, let's consider the possibility of home schooling as another criterion. The modern educational system presupposes the existence of inclusive education, and children with autism can be special users of it. Mainly, classes during such type of training are held at home in a more familiar environment.

\section{Conclusion}

In today's world, in view of some physical and/or psychological diseases, not all people can obtain the necessary skills and knowledge for life on an equal basis with others. Obviously, that the problem of teaching children with ASD is relevant today. The solution of this problem is impossible without state support and further research by scientists, teachers and psychologists as well as generalization of the practical experience of specialists working in this field.

It is really important to pay attention to the problem of developing a scientifically based system of criteria and evaluating the results of their effectiveness in the educational process. Of particular importance is the prospect of research in the field of teaching foreign languages using robotics. Insufficiency in this research field leads to a decrease in the effectiveness of teachers. Undoubtedly, learning foreign languages is a vital necessity for autistic children to expand the boundaries of their intellectual abilities and increase the level of communication abilities. It is in this direction that scientists should make their efforts.

In the context of this work, the analysis of existing educational technologies using robots and without was held. To assess the level of effectiveness of teaching autistic children a foreign language, the following criteria can be used: the status and role characteristics of the teacher, problem statement, the environment, the development of the individual educational plan, and the use of home schooling. It should be noted that due to the imperfection of the technological part of robotic systems, the training of autistic children is more effective with a human-teacher who uses a robot as an assistant.

Both researchers and educators working with autistic children can benefit from this study.

\section{Acknowledgements}

The researchers thank the Institute of psychology and education for the opportunity to participate in the Russian Government Program of Competitive Growth of Kazan Federal University.

\section{References}

Alemi, M., Meghdari, A., Basiri, N.M., \& Taheri A. (2015). The effect of applying humanoid robots as teacher assistants to help Iranian autistic pupils learn English as a foreign language. International 
Conference on Social Robotics. Springer, Cham, 1-10. https://link.springer.com/chapter/10.1007/978-3-319-25554-5_1.

Autism and foreign language learning mini case studies. URL: http://www.languageswithoutlimits.co.uk/resources/AutCaseStudies.pdf (accessed: 09.12.2018)

Bearss, K., Johnson, C., Tristram H., Smith, T., Lecavalier, L., Swiezy, N.B., Aman, M.G., McAdam, D.B., Butter, E.M., Stillitano, C., Minshawi, N.F., Sukhodolsky, D.G., Mruzek, D.W., Turner, K., Neal, T.J., Hallett, V., Mulick, J.A., Green, B., Handen, B. L., Deng, Y., Dziura, J.D., Scahill, L.(2015). Effect of Parent Training vs Parent Education on Behavioral Problems in Children With Autism Spectrum Disorder. JAMA Netwok, 313(15), 1524-1533. https://jamanetwork.com/journals/jama/article-abstract/2275445.

Chang, C.-W., Lee, J.-H., Chao, P.-Y., Wang, C.-Y., \& Chen, G. D. (2010). Exploring the Possibility of Using Humanoid Robots as Instructional Tools for Teaching a Second Language in Primary School. Journal of Educational Technology \& Society, 13(2), 13-24. https://www.jstor.org/stable/pdf/jeductechsoci.13.2.13.pdf.

Esterbrook, S. A., \& Esterbrook, R. L. (2013). Effective methods of diagnostics, training and psychotherapy of children with autistic disorders. Personality Development, Series "C": Psychological and pedagogical Sciences, 2(43), 45-49. https://cyberleninka.ru/article/n/effektivnyemetody-diagnostiki-obucheniya-i-psihoterapii-detey-s-autisticheskimi-narusheniyami.

Hornby, G. (2015). Inclusive special education: development of a new theory for the education of children with special educational needs and disabilities. British Journal of Special Education, 42(3), 234256. https://onlinelibrary.wiley.com/doi/full/10.1111/1467-8578.12101.

Huijnen, C., Lexis, M., \& Witte, L. (2017). Robots as New Tools in Therapy and Education for Children with Autism. International Journal of Neurorehabilitation, 04(04), 278-282. https://www.semanticscholar.org/paper/Robots-as-New-Tools-in-Therapy-and-Education-forHuijnen-Lexis/e724ccd76088d4d38889b81f9de9ca3cbcc02a49

Karpekova, T. A., Esterbrook, R. L., \& Esterbrook, S. A. (2016). Teaching children with autism communicative and speech skills. https://libr.msu.by/bitstream/123456789/1064/1/2875a.PDF.

Mandy, W., Murin, M., Baykaner, O., Staunton, S., Hellriegel, J., Anderson, S., \& Skuse, D. (2016 a). The transition from primary to secondary school in mainstream education for children with autism 
$\begin{array}{lll}\text { spectrum } \quad \text { disorder. } & \text { 20(1), }\end{array}$ https://journals.sagepub.com/doi/full/10.1177/1362361314562616.

Mandy, W., Murin, M., Baykaner, O., Staunton, S., Cobb, R., Hellriegel, J., Anderson, S., \& Skuse, D. (2016 b). Easing the transition to secondary education for children with autism spectrum disorder: An evaluation of the Systemic Transition in Education Programme for Autism Spectrum Disorder $\begin{array}{llr}\text { (STEP-ASD). } & \text { Autism, 20(5), 580-590. }\end{array}$ https://journals.sagepub.com/doi/full/10.1177/1362361315598892 .

Moghadam, A. S., Mahdieh, K., \& Dehbozorgi, Z. (2015). Second Language Learning in Autistic Children

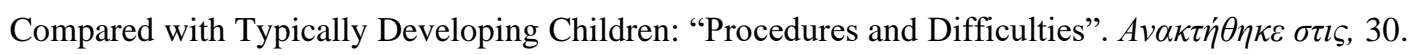
(1), 162-175. http://confnews.um.ac.ir/images/41/conferences/llt/CD50.pdf.

Mukhina, A. Yu. (2017). Formation of sound reproduction and reading skills in children with autism spectrum disorders. Future in research: Materials of the XII international scientific conferenceSofia, 4. 38-47. http://dspace.luguniv.edu.ua/jspui/bitstream/123456789/2615/1/Mookhina.pdf.

Nemenchinskaya, S. M. (2014). Development of communication skills in children with early childhood autism syndrome. Bulletin of the Leningrad state University named after A. S. Pushkin.Publishing house: Pushkin state University of Leningrad (Saint Petersburg), 3(4), 58-65. https://cyberleninka.ru/article/v/razvitie-navykov-obscheniya-u-detey-s-sindromom-rannegodetskogo-autizma.

On Education in the Russian Federation: Federal Law No. 273-FZ of December 29, 2012: adopted by the State Duma on December 21, 2012: approved by the Federation Council on December 26, 2012. http://www.consultant.ru/document/cons doc LAW 140174/

Petrova, I. E., Demidov, P. A., \& Eremeeva, A. A. (2015). Social robots in autism spectrum disorder therapy programs. http://xn--h1aaocodhbaj0a.xn-p1ai/sites/default/files/books/NGU2015.pdf\#page=338 .

Pour, A. G., Taheri, A., Alemi, M., \& Meghdariet, A. (2018). Human-robot facial expression reciprocal interaction platform: case studies on children with autism. International Journal of Social Robotics, 10(2), 179-198. https://link.springer.com/article/10.1007/s12369-017-0461-4.

Recommended BGEP (Basic General Educational Program) «Autism» adopted by the decision of the federal educational-methodical association for general education (protocol of December 22, 2015 № 
415). http://stomfaq.ru/resheniem-federalenogo-uchebno-metodicheskogo-obedineniya-po-ov2/index 18.html

Special Federal State Educational Standard (FSES) for primary school education of children with autism spectrum disorders (ASD). Key points. Prototype. https://alldef.ru/ru/articles/almanah14/specialnyj-federalnyj-gosudarstvennyj-standart-nachalnogo.

Taheri, A. R., Alemi, M., Meghdari, A., PourEtemad, H. R., \& Holderreadb, S.L. (2015). Clinical application of humanoid robots in playing imitation games for autistic children in Iran. Procedia$\begin{array}{llll}\text { Social and Behavioral } \quad \text { Sciences, } & \text { 898-906. }\end{array}$ https://www.sciencedirect.com/science/article/pii/S1877042815005935.

Vanderborght, B., Simut, R., Saldien, J., Pop, C., Rusu, A. S., Pintea, S., Lefeber, D., \& David, D. O. (2012). Using the social robot Probo as a social story telling agent for children with ASD. Interaction $\quad$ Studies, $\quad$ 13(3), 348-372. https://www.jbeplatform.com/content/journals/10.1075/is.13.3.02van.

Voloshin, T. B. (2016). The use of robotics in the system of intensive neurophysiological rehabilitation of patients with autism. Psychiatry, neurology, and medical psychology, 3, (1:5), 96-100. https://www.google.com/url?sa=t\&rct=j\&q=\&esrc=s\&source=web\&cd=2\&ved=2ahUKEwjT246Vi OThAhUBt4sKHTEtAj8QFjABegQIAhAC\&url=http\%3A\%2F\%2Fnbuv.gov.ua\%2Fjpdf\%2Fpsyneur_2016_3_1_19.pdf\&usg=AOvVaw0HA9gFVNZpmPwUYm9gJYSg

Zilberman, N. N., Chekunova, A. B., Gladky, D. A., \& Kulikov, I. A. (2015). Stereotypical representations of children about the status-role characteristics of a social robot (experimental study). Russian Journal of Education and Psychology. 4, 398-417. https://cyberleninka.ru/article/n/stereotipnyepredstavleniya-detey-o-statusno-rolevyh-harakteristikah-sotsialnogo-robota-eksperimentalnoeissledovanie. 